\title{
The relation between daily physical activity and response inhibition control in older adults : An event-related potential study using a Go/NoGo task
}

\author{
Seongryu Bae ${ }^{1}$, Keiko Ogawa ${ }^{2}$ and Katuo Yamazaki ${ }^{3}$ \\ ${ }^{1}$ 早稲田大学大学院スポーツ科学研究科, ×359-1192 埼玉県所沢市三ヶ島2-579-15 (Graduate School of Sport Sciences, \\ Waseda University, 2-579-15 Mikajima Tokorozawa Saitama 359-1192, Japan) \\ 2 広島大学大学院総合科学研究科, 干739-8521 広島県東広島鏡山1-7-1 (Graduate School of Integrated Arts and Sciences, \\ Hiroshima University, 1-7-1 Kagamiyama Higashi-Hiroshima Hiroshima 739-8521, Japan) \\ ${ }^{3}$ 早稲田大学スポーツ科学学術院, テ359-1192 埼玉県所沢市三ヶ島2-579-15 (Faculty of Sport Sciences, Waseda University, \\ 2-579-15 Mikajima Tokorozawa Saitama 359-1192, Japan)
}

Received: December 10,2010 / Accepted: December 6, 2011

\begin{abstract}
We investigated the relationship between daily physical activity level and response inhibition control aspect of cognitive function in older adults using event-related potentials. Twenty-eight Japanese older adults (70.6 \pm 3.8 years) participated in the present study. Daily physical activity (PA) was measured using an accelerometer, including step count and the intensity of PA. Participants were divided on the basis of their step count into "Higher PA group" (more than 10,000 steps/day, $\mathrm{n}=14$ ) and "Lower PA group"(less than 10,000 steps/day, $\mathrm{n}=$ 14). Cognitive function was evaluated by performance, NoGo-N2, and NoGo-P3 while they performed a Go/NoGo task. The results indicated that the Higher PA group exhibited shorter reaction time on Go trials, relative to the Lower PA group. NoGo-P3 amplitude was larger in the Higher PA group compared to the Lower PA group, but NoGo-P3 latency did not differ between groups. PA was positively correlated with NoGo-P3 amplitude. NoGo-N2 component was not related to PA. Thus, PA was more sensitive to monitoring of the outcome of response inhibition rather than pre-motor inhibition in Go/NoGo task. These findings suggest that daily PA is associated with preservation of age-related declines in response inhibition control.
\end{abstract}

Jpn J Phys Fitness Sports Med, 61(2): 169-176 (2012)

Keywords : Daily physical activity, Response inhibition control, cognitive function, eventrelated brain potentials, older adults

\section{緒言}

加齢とともに身体機能のみならず，記憶，注意，抑制 といった認知機能に低下が生じる1-4)。近年，加齢に伴 う認知機能低下を抑え，高齢期に扮ける生活の質を良好 に保つ有効な手段の一つとして身体活動が注目されてい $3^{1,5)}$.

65歳以上の女性高齢者（5,925名）を対象に，質問紙 を用いて身体活動と認知機能との関連を検討した横断調 査では，両者の間に正の相関関係を認めている ${ }^{6)}$. 同様 な調查によってBarnes et $\mathrm{al}^{7}{ }^{7}$ も，心肺体力の高い高齢 者のほうが低い高齢者よりも認知機能は高いことを報告 している.

質問紙以外にも，身体活動と認知機能との関係を調 ベる方法として，認知課題遂行中の反応時間（reaction time : 以下RT), 正反応数, 事象関連電位 (event-related potentials : 以下ERPs）の測定が有効である ${ }^{1,5)}$. ERPsは, 刺激呈示や反応生起など， ある特定の事象に関連して生 じる一過性の脳電位変動であり, 脳内情報処理過程を高 時間分解能で検討するッールとして用いられている8 ERPsのなかでもP3成分は，認知機能と身体活動との関 係を検討するうえで広く用いられている。P3は刺激提 示後約300-600msに最大振幅を示す陽性電位であり，そ の振幅は標的刺激へ配分された注意資源量を反映し，頂 点潜時は刺激評価に要した時間を反映すると解釈されて いる ${ }^{9)}$. 高齢者と若年者の心肺体力の違いによるP3変化 を検討した研究では, 年齢に関係なく心肺体力の高い群 のほうが低い群よりもP3振幅が大きいことが報告され 
ている10,11)。さらに，Hillman et al. ${ }^{1)}$ は，高齢者を身体 活動レベルの差異によって 3 群に分け, 認知暮藤課題遂 行中のP3を若年者と比較した。午の結果，P3潜時は若 年者よりも高齢者のほうで長かった。高齢者では身体活 動レベルの低い群になるほどP3潜時が長いことを示し, 身体活動の遂行が高齢者の認知処理速度に関連すること を示唆している.

認知機能と身体活動との関連を調べた研究では従来, 実行機能の役割に焦点が当てられてきた ${ }^{5,12)}$ 。実行機能 とは，自分の置かれた環境下で最適な行動を選択し，実 行するために必要となる機能を指し, 主に前頭前野の 担うワーキングメモリ，注意，干渉制御，反応抑制な ぞが該当する ${ }^{13)}$ ，そのなかの反応抑制は，進行中の反 応を素早くかつ確実に抑制するための機能であり ${ }^{14)}$ ，他 の実行機能と同様に加齢とともに衰退する ${ }^{15,16)}$. 従来, ERPsを用いた反応抑制制御の研究では, 高頻度提示さ れるGo刺激に対して素早く反応する一方で, 低頻度提 示されるNoGo刺激に対しては反応を抑制するGo/NoGo 課題が多く用いられてきた。 NoGo刺激提示によって 惹起するNoGo-N2とNoGo-P3は，加齢による反応抑制 機能の低下に伴って振幅值が低下する ${ }^{15,17)}$. NoGo-N2 は, NoGo刺激呈示後約250-350ms間に前頭-中心部に 出現する陰性成分であり, 反応実行の前段階での反応 プログラミングの修正や抑制に関係している ${ }^{18,19)}$ 。一 方，NoGo-P3は，NoGo刺激呈示後約300-600msに前頭 一中心部で出現する陽性成分であり, 頭頂部優位に出現 するP3成分 ${ }^{20)}$ とは頭皮上分布が異なることから（NoGoanteriorization: $\mathrm{NGA})^{21,22)}$, 両者の機能的意義は異なる と考えられている.NoGo-P3の機能的意義については, 反応抑制そのものを反映するという解釈 ${ }^{23)}$ と，反応抑制 の出力に対するモニタリングを反映するという解採があ $3^{18,24)}$.

Kramer et $a l^{25)}$ は加齢と反応抑制機能との関連につい て, 健常高齢者のNoGo刺激に対する反応抑制の成功率 が若年者よりも低いことを示している。ささらにERPsに ついても, 高齢者の反応抑制機能の低下はNoGo-N2振 幅 $^{17)}$ およびNoGo-P3振幅の減衰として反映されるとい $う^{15)}$.

高齢者の身体活動量と実行機能との関係をERPsで検 討した従来の研究を概観すると, 注意機能11), 干涉制 御1)，ワーキングメモリ ${ }^{26)}$ に焦点を当てたものは見られ るものの, Go/NoGo課題を用いて高齢者の日常身体活 動量とNoGo-N2拈よびNoGo-P3の関係を検討した研究 は見当たらない

そこで本研究では, 高齢者の日常身体活動量と反応 抑制制御との関係を, NoGo-N2抄よびNoGo-P3成分に よって検討することを目的とした，高齢者における身体 活動量と実行機能との間には正の相関関係が認められて
いることから ${ }^{6.7)}$ ， 日常の身体活動量の違いは反応抑制 制御にも関係すると考えられる。したがって，本研究に おいて身体活動量が多い高齢者は少ない高齢者に比心゙, NoGo-N2成分およびNoGo-P3成分の高振幅が予想され た.

身体活動量と認知機能との関倸を検討した先行研究で は，身体活動量を心肺体力27)あるいは自己記入式による 質問紙 ${ }^{1,26)}$ によって評価してきた。心肺体力に関与する 諸因子には，身体活動だけでなく ${ }^{28,29)}$ ，遺伝的素因 ${ }^{28,30)}$, 身体組成 ${ }^{31}$ などの要因も含まれる。また，日常生活下に 低強度の身体活動が多い高齢者の場合には，心肺体力だ けでなく，1日の生活を通した身体活動量を客観的に評 価する必要がある。そこで本研究は，加速度計付き歩数 計を用いることで高齢者の日常的な身体活動量を計測 し，定量化することとした。

\section{方 法}

参加者および手続き 精神疾患や神経疾患を有さず，矯 正視力が正常な高齢者30名（男性13名，女性17名：平均 $70.5 \pm 3.8$ 歳）が日常の身体活動量測定とGo/NoGo課題を 遂行した。参加者の属性扔よび生活習慣は, 自己記入式 質問紙によって聴取した。さらに，抑うつ状態が高齢者 の認知機能低下の一要因となることから ${ }^{32)}$, Zungの自 己評価式抑うつ性質問紙 ${ }^{33,34)}$ を参加者の精神衛生調査に 用いた。参加者は連続10日間にわたって加速度計付き歩 数計を装着し，日常身体活動量を測定した，測定後，脳 波に対するアーチファクト混入が過多だった 2 名を除外 した28名（男性12名，女性16名：平均 $70.6 \pm 3.8$ 歳）を最 終的な検討対象とした。

参加者には，本研究の目的，測定内容，参加に伴う不 利益などについて文書拈よび口頭によって詳細に説明 し，書面での研究参加の同意を得た。本研究は早稲田大 学における「人を対象とする研究に関する倫理審査委員 会」の承認を得て実施した。

身体活動量の測定 身体活動量の測定には，加速度計 付き歩数計 (Kenz Lifecorder-Ex，スズケン社製：以 下ライフコーダ）を用いた。連続10日間の装着期間中, ライフコーダの配布・回収日, 適応日の合計 3 日間を 除外した 7 日間（月曜日から日曜日まで）のデータを 分析対象とした。 1 週間に扮ける1日当たりの平均歩 数を求め, Park et al. ${ }^{35)}$ の先行研究を参考に 1 万歩を 超えた参加者（14名）を身体活動量の多い群（higher physical activity: Higher PA群), 1 万歩未満の参加者 (14 名）を身体活動量の少ない群（lower physical activity: Lower PA群）として分類した，身体活動の強度はライ フコーダ強度レベル1-3を低強度（<3 METs），4-6を 中等度強度（3-6 METs），7-9を高強度（>6 METs） 
とし, 各群におけるそれぞれの強度別活動時間を求めた。 身体活動量の指標であるEx（METs・h）に関しては, $3 \mathrm{METs}$ 以上の身体活動を 1 週間の合計で求めた.

測定期間中は，同一のライフコーダを使用し，起床時 から就寝時まで（入浴時を除外）右または左の腰部側面 に装着し, 装着部位を変更しないように指示した。また, 測定期間中のライフコーダ装着の有無, 水中運動や自転 車運動の有無, 外出の有無等を生活日誌に記入した。 ラ イフコーダ装着自体が介入となり一時的に身体活動量が 増加する可能性があるため参加者にはできるだけ普段と 同様の生活を送るように教示し，ライフコーダ装着期間 中は参加者自身には自らの活動量は確認できないように 設定した。

Go/NoGo課題 Go/NoGo課題遂行中の脳波測定はシー ルドルーム内の椅子に座った状態で行った。視覚刺激は 参加者の $1 \mathrm{~m}$ 前方に設置したモニタ上に提示した。モニ 夕中央部に注視点 $(+)$ が500ms間提示された後, 実線 あるいは破線の四角枠で囲まれた緑色円あるいは赤色円 がランダムに提示された。参加者には, 実線枠の緑色円 と赤色円に対して, 左右第 3 指で可能な限り正確かつ素 早くキー上げ反応するように教示した（Go刺激）. 色と 反応肢との関係は参加者間でカウンターバランスをとっ た。一方, 破線枠に囲まれた緑色円と赤色円に対しては, 反応をしないように教示した（NoGo刺激）．Go刺激と NoGo刺激の提示確率はそれぞれ80\%と20\%であり，刺 激提示時間は $150 \mathrm{~ms} ゙$ あった。刺激間間隔を $1500 \mathrm{~ms}$ し， 1 ブロック 120 試行を合計 3 ブロック行った.

脳波記録と解析 脳波は国際10-20法に従い，64チャン ネルのエレクトロキャップ (Electro-cap International 社製）により，頭皮上23部位からQuickAmp（Brain Products社製）を用いて導出した。脳波はオフラインで 両耳朵の平均電位を基準に再基準化した。眼電罒は両外 眼角 $1 \mathrm{~cm}$ 品水平眼電図, 左眼中心上下 $2 \mathrm{~cm}$ 号垂直 眼電困を記録した。脳波と眼電図はバンドパスフィルタ 0.016-120Hzで導出し, サンプリング周波数は $500 \mathrm{~Hz}$ あり, 電極抵抗值は $5 \mathrm{k} \Omega$ 以下とした。

脳波データはGoとNoGo刺激前100msからGoとNoGo 刺激提示後 $900 \mathrm{~ms}$ の $1000 \mathrm{~ms}$ 区間を解析対象とした。眼 球運動によるアーチファクトはGratton \& Coles法 ${ }^{36)}$ 用いて修正した。 $\pm 100 \mu \mathrm{V}$ 以上のアーチファクトを含 む試行は分析から除外し, 正反応試行の脳波データにつ いてGo刺激とNoGo刺激提示時点をトリガにして加算平 均した。加算平均で得られたERPsに対してバンドパス フィルタ（0.1-30 Hz，12 dB/octave）を適用し，振幅 值は刺激提示前 $100 \mathrm{~ms}$ 区間の平均電位をべースラインと して計測した。 NoGo-N2振幅值はNoGo刺激提示後150-
300ms区間内における最大陰性電位としたＮNoGo-P3振 幅值はNoGo刺激提示後300-600ms区間内における最大 陽性電位とした。各ERP成分の潜時は刺激提示時点から 頂点振幅までの時間とした。 RTは刺激提示時点から反 応キー上げまでの時間を計測し，150-850msの範囲にあ る試行のみを分析対象とした，RTの除外基準は脳波の 加算平均処理にも適用した。

統計検定 参加者の身体的および生活習慣の特徴, 身体 活動量, Go/NoGo課題遂行中のRTおよびエラー率に関 して, 対応のないt検定を用いて群間（Higher PA群/ Lower PA群間）比較を行った。 NoGo-N2とNoGo-P3成 分の振幅および潜時に関しては, 部位 $(\mathrm{Fz} \cdot \mathrm{FCZ} \cdot \mathrm{Cz}$. $\mathrm{Pz}) \times$ 群 (Higher PA群・Lower PA群)の 2 要因分散分 析を適用した。 Mauchlyの球面性検定の結果，球面性が 仮定されなかった場合には, Greenhouse-Geisserのイ プシロンを用いて自由度，有意確率を再計算した。主効 果と交互作用が認められた場合は, Bonferroni法を用い て下位検定を行った。また，最大振幅を示した部位の NoGo-N2振幅およびNoGo-P3振幅と身体活動量の指標 (歩数およびEx）との関係について，参加者の特性（年 齢, 性別, 体格指数 (body mass index: 以下BMI), 教育歴) を制御変数とした偏相関分析を用いて検討した，有意確 率は $5 \%$ とし，すべての統計検定はSPSS for Windows Ver. 17.0を用いて行った.

\section{結果}

身体的および生活習慣の特徵 参加者の身体的特徵と生 活習慣の特徵を表 1 に示した。年齢，身長，体重，教育 年数, 睡眠時間についてHigher PA群とLower PA群間 で差はなかった。Zung自己評価式抑うつ得点は，すべ ての参加者が正常範囲（正常範囲：39点以下）にあり, 群間に差はなかった。一方, 週当たりの運動実施回数 （1日30分以上）は, Higher PA群がLower PA群よりも 有意に多かった $(\mathrm{t}(26)=3.58, \mathrm{p}<.001)$.

身体活動量の比較 表 2 はライフコーダによって測定さ れた各群の身体活動量である。身体活動量指標はHigher PA群のほうがLower PA群より有意に高い值を示した ( 1 日当たりの平均歩数： $\mathrm{t}(26)=7.82, \mathrm{p}<.001 ; 1$ 週間 当たりのEx： $t(26)=9.11, p<.001)$. さらに，1日当 たりの強度別活動時間分布に関しても, 中等度強度にお いてHigher PA群の活動時間がLower PA群よりも有意 に長かった $(\mathrm{t}(26)=8.57, \mathrm{p}<.001)$.

行動指標 Go刺激およびNoGo刺激に対する行動データ を表 3 に示した。Go刺激に対するRTを群間比較した結 果, Lower PA群よりもHigher PA群のほうがRTは短かっ 
Table 1. Group means for participant characteristics.

\begin{tabular}{lcc}
\hline & Higher PA $(\mathrm{n}=14)$ & Lower PA $(\mathrm{n}=14)$ \\
\hline Age (years) & $70.5 \pm 3.8$ & $70.7 \pm 4.0$ \\
Sex (Men : Women) & $7: 7$ & $5: 9$ \\
Height $(\mathrm{cm})$ & Men $(164.5 \pm 5.7)$, Women $(151.5 \pm 5.2)$ & Men $(164.7 \pm 7.2)$, Women $(154.7 \pm 4.6)$ \\
Weight (kg) & Men $(63.7 \pm 8.9)$, Women $(46.0 \pm 5.3)$ & Men $(58.9 \pm 3.9)$, Women $(52.2 \pm 7.5)$ \\
\hline Years of education (years) & $13.0 \pm 1.8$ & $13.0 \pm 2.3$ \\
Sleeping hour (time/day) & $6.2 \pm 1.0$ & $6.3 \pm 0.8$ \\
Exercise frequency (day/week) & $5.0 \pm 1.5$ & $3.0 \pm 1.8$ \\
Zung self-rating depression & $37.1 \pm 7.1$ & $36.5 \pm 7.9$ \\
\hline
\end{tabular}

Values are means \pm SD. Significantly different by Student's t-test, ${ }^{* * *} \mathrm{p}<0.001$

PA: physical activity

Table 2. Comparison of physical activity levels between Higher and Lower PA groups

\begin{tabular}{|c|c|c|}
\hline & Higher PA $(n=14)$ & Lower PA $(n=14)$ \\
\hline Step counts (steps/day) $* * *$ & $12939.0 \pm 1999.0$ & $8037.0 \pm 1228.0$ \\
\hline Ex $($ Mets $\cdot h /$ week $) * * *$ & $24.1 \pm 5.5$ & $8.7 \pm 3.1$ \\
\hline Light PA (min/day) & $79.7 \pm 22.5$ & $69.3 \pm 20.4$ \\
\hline Moderate PA (min/day) $* * *$ & $48.6 \pm 11.5$ & $18.4 \pm 6.5$ \\
\hline Vigorous PA (min/day) & $1.6 \pm 2.1$ & $0.6 \pm 0.5$ \\
\hline
\end{tabular}

Values are means \pm SD. Significantly different by Student's t-test, ${ }^{* * * *} \mathrm{p}<0.001$

た $(\mathrm{t}(26)=2.62, \mathrm{p}<.01)$. Go刺激 $(\mathrm{t}(26)=1.12$, n.s. $)$ とNoGo刺激 $(\mathrm{t}(26)=0.70$, n.s.) におけるエラー率には 群間差が見られなかった。

NoGo-P3成分 NoGo刺激におけるERPsの総加算波形 を図 1 に示した。平均加算回数は $54 \pm 12$ 回であった。 NoGo-P3潜時と振幅について部位 $\times$ 群の 2 要因分散分 析を実施した結果, NoGo-P3振幅值はLower PA群よ りHigher PA群のほうで有意に大きかった $(\mathrm{F}(1,26)=$ 4.33, $\mathrm{p}<.05)$. 部位の主効果が認められ下位検定を行っ た結果, $\mathrm{Pz}$ よりも Fz, FCzおよびCzのNoGo-P3振幅が大 きかった $(\mathrm{Fz} ; \mathrm{p}<.01, \mathrm{FCZ} ; \mathrm{p}<.001, \mathrm{CZ} ; \mathrm{p}<.001)$. また，群×部位の交互作用が有意だったため $(\mathrm{F}(3,24)$ $=4.20, \mathrm{p}<.05, \varepsilon=.70)$, 各部位における群間比較を 行った結果, $\mathrm{C} z$ とPZでHigher PA群のほうがLower PA 群よりもNoGo-P3振幅が大きかった(いずれも $\mathrm{p}<.01)$ (図 2). 各群における部位間の比較を行った結果, Higher PA群ではPzよりもFCzおよびC $z$ な゙大きかった $(\mathrm{p}$ <.001). Lower PA群ではPzよりも Fz， FCzおよびCzの NoGo-P3振幅が大きかった $(\mathrm{F} z ; \mathrm{p}<.01, \mathrm{FCZ} ; \mathrm{p}<.001$, $\mathrm{Cz} ; \mathrm{p}<.001)$.

NoGo-P3潜時については, 部位の主効果が認められ(F $(3,24)=13.93, \mathrm{p}<.001, \varepsilon=.99)$ 下位検定を行った結 果, $\mathrm{FCZ}$ のほうが他部位よりも短潜時だったいずれも $\mathrm{p}<.01)$. 群間の違いは見られなかった $(\mathrm{F}(1,26)=0.17$, n.s.).

最大振幅を示した $\mathrm{Fz}, \mathrm{FCz}, \mathrm{Cz}$ 部位のNoGo-P3振幅 と身体活動量の指標（歩数および $\mathrm{Ex}$ ) との関係を偏相 関分析によって検討した結果, $\mathrm{C} z$ 部位のNoGo-P3振幅 と歩数 $(r=0.44, p<.05)$ および $\operatorname{Ex}(r=0.53, p<.01)$ と
Table 3. Group means for behavioral performance data

\begin{tabular}{lcc}
\hline & Higher PA $(\mathrm{n}=14)$ & Lower PA $(\mathrm{n}=14)$ \\
\hline RT $(\mathrm{ms}) * *$ & $483.4 \pm 44.4$ & $533.8 \pm 56.6$ \\
Error rate & & \\
$\quad$ Go trials (\%) & $6.3 \pm 3.7$ & $8.0 \pm 4.3$ \\
$\quad$ NoGo trials (\%) & $7.8 \pm 4.8$ & $9.1 \pm 5.0$ \\
\hline
\end{tabular}

Values are means $\pm \mathrm{SD}$

Significantly different by Student's t-test, ${ }^{*} \mathrm{p}<0.05^{* *} \mathrm{p}<0.01$

の間にそれぞれ正の相関関係が認められた。

NoGo-N2成分 NoGo-N2振幅と潜時についてそれぞれ群 ×部位の 2 要因分散分析を行った。 その結果, NoGo-N2 振幅においては，部位の主効果が有意であった $(\mathrm{F}(3,24)$ $=4.91, \mathrm{p}<.01, \varepsilon=.77)$. 下位検定の結果， FCzより $\mathrm{Pz}$ で 大きかった $(\mathrm{p}<.05)$.

NoGo-N2潜時においても部位の主効果が認められ ( F $(3,24)=5.34, \mathrm{p}<.01, \varepsilon=.77)$, 下位検定を行った結果, $\mathrm{Pz}$ よ $\mathrm{F} z$ で長かった $(\mathrm{p}<.01)$.

NoGo-N2振幅 $(\mathrm{F}(1,26)=1.64$, n.s.) と潜時 $(\mathrm{F}(1,26)$ $=2.14$, n.s.) いずれも群間の違いは認められなかった.

最大振幅を示したPz部位のNoGo-N2振幅と身体活動 量の指標（歩数およびEx）との間には相関関係が見ら れなかった。

\section{考察}

本研究は, 高齢者における日常の身体活動量と反応抑 制制御との関係をNoGo-N2成分とNoGo-P3成分を用い て検討した。その結果，身体活動量が多い高齢者は少 ない高齢者に比べNoGo-P3振幅が大きかった。さらに， 身体活動量とNoGo-P3振幅との間に正の相関関係が認 められた。一方, NoGo-N2振幅に関しては，身体活動 量との関係が見られなかった。 以上のことから，高齢者 における日常身体活動量の違いが反応抑制制御に関係す ることが示唆された。この関係は, 反応プログラミング 段階での抑制よりも反応抑制の結果に対するモニタリン グに敏感に表れることが示唆された.

NoGo-P3成分は, 反応抑制に関連した成分であり ${ }^{22)}$, 反応抑制の出力をモニタしている可能性も指摘されてい 

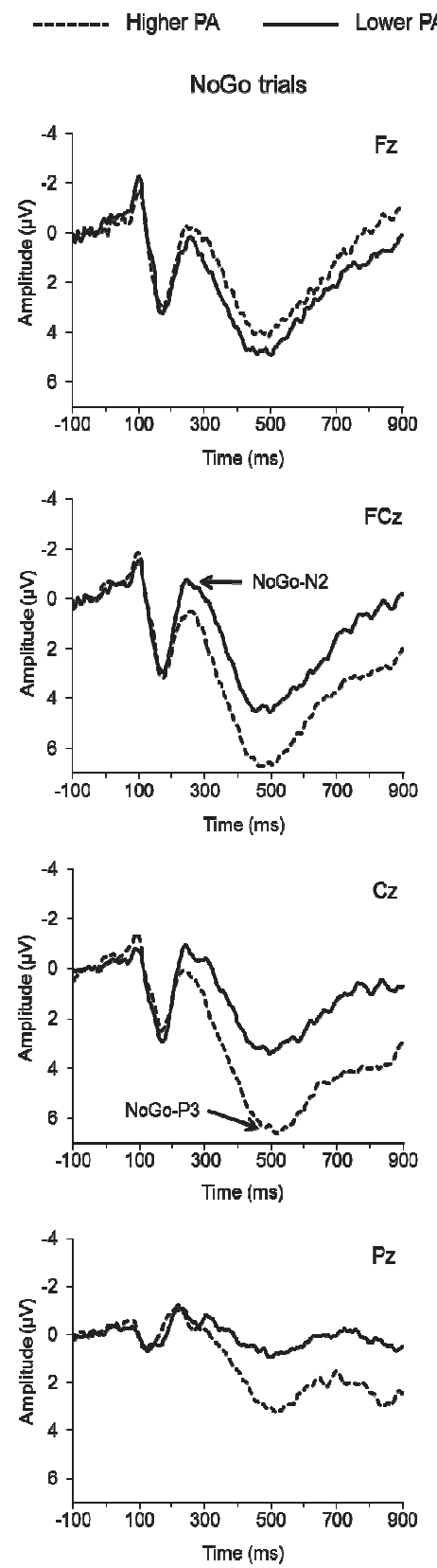

Fig 1. Grand averaged waveforms for physical activity levels on NoGo trials at four midline electrode sites ( $F z$, $\mathrm{FC} z, \mathrm{C} z, \mathrm{Pz}$ ).

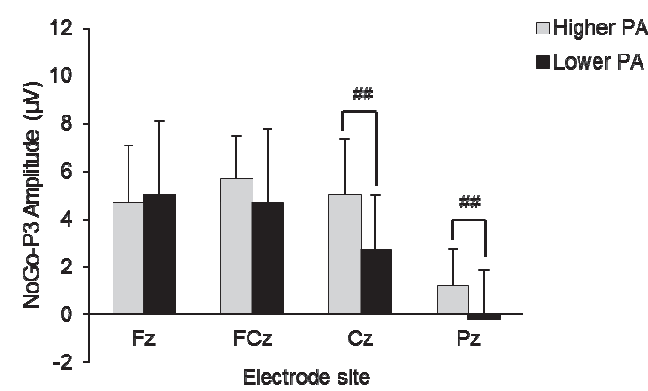

Fig 2. Mean NoGo-P3 amplitude for electrode sites across groups (means $\pm \mathrm{SD}$ )
る。その発生源として行動モニタリング機能に関係の 深い前帯状皮質 (anterior cingulate cortex：ACC) が 推定されている23.37)。行動モニタリング機能を検討し たERPs研究では, 前頭中心部優位に出現するエラー関 連陰性電位（error-related negativity potential：以下 ERN）が用いられている38). Themanson et al. ${ }^{39}$ は，心 肺体力とERNとの関倸を検討した結果，正確性を強調 した課題条件において，心肺体力が低い者に比べ高い者 のほうでERN振幅が大きいことを示した。この結果は, 反応に対するエラーを検出し, 修正していく行動モニ夕 リング機能が身体運動と関連することを示唆している. また, Beste et al. ${ }^{15)}$ は，NoGo-P3振幅が若年者に比べ健 常高齢者で低振幅を示し，加齢によって反応抑制のモ二 タリング機能が衰えることを横断研究により報告した。 これらの先行研究の結果より, 本研究において身体活動 量が少ない高齢者に比べ多い高齢者でのNoGo-P3高振 幅は反応抑制に対するモニタリングにも身体活動が関 わっていることを示唆する，また，加齡によって低下す る反応抑制モニタリング機能を身体活動の遂行によって 遅らせる可能性も考えられた。

Picton et al. ${ }^{40)}$ は, P3成分の加齢変化を振幅減少, 潜 時遅延, 頭皮上分布の前頭部への移行によって特徵づけ ている. Hatta et al. ${ }^{41)}$ は, 高齢者を対象に運動群と非運 動群間のP3成分の変化を検討した結果，運動群ではP 部位でのP3振幅が大きかったが, 非運動群ではFzと Pz の両部位においてP3振幅が大きな值を示した。この結 果から，身体運動は加齢による頭皮上分布の変化を抑元 る可能性が示唆されている。本研究において, Higher PA群ではNoGo-P3の優勢部位と言われている $\mathrm{FCz}$ と $\mathrm{Cz}$ 部位で最大振幅を示した。一方, Lower PA群ではFz部 位でも高振幅を示した。この結果は，P3成分と同様に NoGo-P3成分に扔ける頭皮上分布の変化が身体活動量 の違いに関係する可能性が示唆された。

一般に, NoGo-N2成分は前頭-中心部優勢に分布し, 反応実行初期の反応プログラミング段階での抑制を反映 すると考えられている ${ }^{18,42)}$. 本研究では, NoGo-N2の頭 皮上分布が前頭一中心部に比べて頭頂部よりであった。 したがって，本研究に扔けるNoGo-N2成分の機能的意 義に関しては慎重に解釈すべきところである，現象記述 的には, NoGo-N2振幅の群間差を示さなかったことか ら，日常の身体活動量と反応プログラミングの抑制の間 には関連のないものと推察される。

NoGo-P3振幅がLower PA群より Higher PA群で有意 に大きかったにも関わらず，NoGo刺激に対するエラー 率には群間差が見られなかった。身体活動量とERPsと の関係を調べた先行研究のなかには，RTやエラー率に 差がないものの, ERPsの有意な変化を報告した研究が ある。たとえば, Hillman et al. ${ }^{1}$ は身体活動量との関係 
をP3には認めたものの，RTには見出していない。また， 反応正解率と身体活動量との関係を認めた研究では, 簡 単な課題条件よりも複雑な課題条件でその関係が顕著で あると報告している ${ }^{43)}$ 。これらの先行研究より，身体活 動量との関係は，パフォーマンスよりもERPsに敏感に 表れ,パフォーマンスにおける違いを確認するためには, より実行機能を要求する課題設定が必要条件と考えられ る。本研究の対象者はすべて健常高齢者であり, 課題難 度もエラー率に群間差を生じさせる程度ではなかった可 能性が高い。その一方で, NoGo-P3振幅には身体活動 量の違いが鋭敏に表れたものと考えられる。

従来, 刺激検出から評価, 反応選択, 反応実行といっ た脳内情報処理過程を検討するためにRTが用いられて きた ${ }^{44)}$. Spirduso ${ }^{45)}$ は，高齢者と若年者に対して，それ ぞれ運動群と非運動群に振り分けてRTを比較した結果， 若年者/運動群は他の 3 群よりも短い一方で，若年者/非 運動群よりも高齢者/運動群のほうが短い傾向にあるこ とを報告した。この結果は， RTは加齢に伴って遅延す るものの, 習慣的運動によってその遅延をある程度遅ら せる可能性を示唆しており, 本研究のHigher PA群でみ られたGo刺激に対するRT短縮もこの見解を支持するも のである.

米国スポーツ医学会 (ACSM) によれば46)，1 週間当た り 5 日以上，1日30分以上の中等度強度の身体活動が 健康增進や疾病予防のために推奨されている。 さらに, 「健康づくりのための運動指針2006」47)では，身体活動 量の目標值が週23Ex以上の活発な身体活動と定められ ている. 本研究に扔いても 1 日当たりの歩数が 1 万歩 以上のHigher PA群は，中等度強度の身体活動時間が 1 日当たり $48.6 \pm 3.1$ 分であった。ささらに，1 週間当たりの

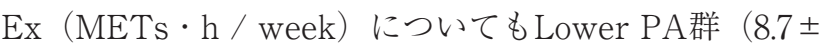
$0.8 \mathrm{Ex})$ より Higher PA群 $(24.1 \pm 1.5 \mathrm{Ex})$ で有意に多く, Higher PA群の身体活動量はACSM㧍よび「健康づくり のための運動指針2006」の基準と対応を示した。

最後に本研究の方法論上の限界を指摘しておく。本研 究では横断的デザインを採用したことから，身体活動と 反応抑制機能との因果関係を明らかにすることはできな い．また， 1 日当たりの平均歩数 ( 1 万歩基準)によっ て参加者をHigher PA群とLower PA群に分けたため, 両群ともに中等度レベルの身体活動を行う者を含んでい た可能性がある。したがって今後は，多人数の高齢者を 対象としたうえで, 縦断的研究による検討が必要である.

\section{結語}

本研究では, Go/NoGo課題を用いてNoGo-N2, NoGo-P3成分拉よび行動指標が高齢者の日常身体活動量の 違いによってどのように異なるのかを検討した。その結 果, Lower PA群よりHigher PA群のほうでNoGo-P3が
大きかった。さらに，身体活動量と NoGo-P3振幅との 間に正の相関関係が認められた。一方，NoGo-N2振幅 に関しては，身体活動量との関係が見られなかった，以 上のことから，高齢者における日常身体活動量の違いが 反応抑制制御に関係することが示唆された。この関係は, 反応プログラミング段階での抑制よりも反応抑制の結果 に対するモニタリングに敏感に表れる可能性が示唆され た。

\section{謝 辞}

本研究の実施にあたり，ご協力いただきました関係者お よび参加者の皆様に御礼申し上げます。

\section{引 用 文 献}

1) Hillman $\mathrm{CH}$, Belopolsky AV, Snook EM, Kramer AF, McAuley E. Physical activity and executive control: Implication for increased cognitive health during older adulthood. RQES, 75: 176-185, 2004.

2) Wecker NS, Kramer J, Wisniewski A, Delis DC, Kaplan E. Age effects on executive ability. Neuropsychology, 14: 409-414, 2000.

3) Milham MP, Erickson KI, Banich MT, Kramer AF, Webb A, Wszalek T, Cohen NJ. Attentional control in the aging brain: Insights from an fMRI study of the stroop task. Brain Cogn, 49: 277-296, 2001.

4) Park DC, Lautenschlarger G, Hedden $T$, Davidson N, Amith AD, Smith PK. Models of visuospatial and verbal memory across the life span. Psychol Aging, 17: 299-320, 2002

5) Hillman $\mathrm{CH}$, Erickson KI, Kramer AF. Be smart, exercise your heart: Exercise effects on brain and cognition. Nat Rev Neurosci, 9: 58-65, 2008.

6) Yaffe K, Barnes D, Nevitt M, Lui LY, Covinsky K. A prospective study of physical activity and cognitive decline in elderly women. Arch Intern Med, 161: 1703-1708, 2001.

7) Barnes DE, Yaffe K, Satariano WA, Tager IB. A longitudinal study of cardiorespiratory fitness and cognitive function in healthy older adults. $J$ Am Geriatr soc, 51: 459-465, 2003

8）入戸野宏. 心理学のための事象関連電位ガイドブック, 京都: 北大路書房, 1-30, 2005.

9) Polich J. Updating P300: An integrative theory of P3a and P3b. Clin Neurophysiol, 118: 2128-2148, 2007.

10) McDowell K, Kerick SE, Santa maria DL, Hatfield BD. Aging, physical activity, and cognitive processing: an examination of P300. Neurobiol Aging, 24: 597-606, 2003.

11) Pontifex MB, Hillman $\mathrm{CH}$, Polich J. Age, physical fitness, and attention: P3a and P3b. Psychophysiology, 46: 379-387, 2009 .

12) Colcombe S, Kramer AF. Fitness effects on the cognitive function of older adults: A Meta-Analytic Study. Psychol Sci, 14: 125-130, 2003.

13) Funahashi S. Neuronal mechanisms of executive con- 
trol by the prefrontal cortex. Neurosci Res, 39: 147165,2001

14) Johnstone SJ, Barry R, Markovska V, Dimoska A, Clarke AR. Response inhibition and interference control in children with AD/HD: A visual ERP investigation. Int J Psychophysiol, 72: 143-153, 2009.

15) Beste C, Willemssen R, Saft C, Falkenstein M. Response inhibition subprocesses and dopaminergic pathways: Basal ganglia disease effects. Neuropsychologia, 48: 366-373, 2010.

16) Buckner RL. Memory and executive function in aging and $\mathrm{AD}$ : Multiple factors that cause decline and reserve factors that compensate. Neuron, 44: 195-208, 2004.

17) Czigler I, Csibra G, Ambro A. Aging, stimulus identification and the effect of probability: an event-related potential study. Biol Psychol, 43: 27-40, 1996.

18) Falkenstein M, Hoormann J, Hohnsbein J. ERP components in Go/Nogo tasks and their relation to inhibition. Acta Psychol, 101: 267-291, 1999.

19) Ruchsow M, Groen G, Kiefer M, Hermle L, Spitzer M, Falkenstein M. Impulsiveness and ERP components in a Go/Nogo task. J Neural Transm, 115: 909-915, 2008.

20) Sutton S, Tueting P, Zubin J, John ER. Evoked potential correlates of stimulus uncertainty, Science, 150: 1187-1188, 1965.

21) Lehmann D, Ozaki H, Pal I. EEG alpha map series: brain micro-states by space-oriented adaptive segmentation. Electroencephalogr Clin Neurophysiol, 67: 271-288, 1987.

22) Fallgatter AJ, Mueller ThJ, Strik WK. Age-related changes in the brain electrical correlates of response control, Clin Neurophysiol, 110: 833-838, 1999.

23) Smith JL, Johnstone SJ, Barry R. Movement-related potentials in the Go/NoGo task: The P3 reflects both cognitive and motor inhibition. Clin Neurophysiol, 119: 704-714, 2008.

24) Schmajuk M, Liotti M, Busse L, Woldorff MG. Electrophysiological activity underlying inhibitory control processes in normal adults. Neuropsychologia, 44: 384-395, 2006.

25) Kramer AF, Humphrey DG, Larish JF, Logan GD, Strayer DL. Aging and inhibition: Beyond a unitary view of inhibitory processing in attention. Psychol Aging, 9: 491512, 1994.

26) Hillman CH, Kramer AF, Beloposky AV, Smith DP. A cross-sectional examination of age and physical activity on performance and event-related brain potentials in a task switching paradigm. Int J Psychophysiol, 59: 30-39, 2006.

27) Themanson JR, Hillman CH. Cardiorespiratory fitness and acute aerobic exercise effects on neuroelectric and behavioral measures of action monitoring. Neuroscience, 141: 757-767: 2006.

28) Dvorak RV, Tchernof A, Starling RD, Ades PA, DiPietro L, Poehlman ET. Respiratory fitness, free living physical activity, and cardiovascular disease risk in older individuals: a doubly labeled water study. J Clin Endocrinol Metab, 85: 957-963, 2000.

29) Paffenbarger RSJr, Blair SN, Lee IM, Hyde RT. Measurement of physical activity to assess health effects in free-living population. Med Sci Sport Exerc, 25: 6070, 1993.

30) Marcuello A, Martinez-Redondo D, Dahmani Y, Casajus JA, Ruiz-Pesini E, Montoya J, Lopez-Perez MJ, Diez-Sanchez C. Human mitochondrial variants influence on oxygen consumption. Mitochondrion, 9: 27-30, 2009.

31) Wong SY, Chan FW, Lee CK, Li M, Yeung F, LumCC, Choy DT, Woo J. Maximum oxygen uptake and body composition of healthy Hong kong Chinese adult men and women aged 20-64 years. J Sports Sci, 26: 295302, 2008.

32) Crocco EA, Castro K, Loewenstein DA. How latelife depression affects cognition: Neural mechanisms. Curr Psychiatry Rep, 12: 34-38, 2010.

33) Zung WWK. A self-rating depression scale. Arch Gen Psychiatry, 12: 63-70, 1965.

34）福田一彦, 小林重雄. 自己評価式抑うつ性尺度の研究, 精神神経学雑誌, 75: 673-679, 1973.

35) Park S, Park H, Togo F. Year-long physical activity and metabolic syndrome in older Japanese adults: Cross-sectional data from the Nakanojo study. $J$ Gerontol A Biol Sci, 63: 2008.

36) Gratton G, Coles MGH, Donchin E. A new method for off-line removal of ocular artifact. Electroencephalogr Clin Neurophysiol, 55: 468-484, 1983.

37) Beste C, Saft C, Andrich J, Gold R, Falkenstein M. Response inhibition in Huntington's disease - A study using ERPs and sLORETA. Neuropsychologia, 46: 12901297, 2008.

38) Holroyd CB, Coles MG. The neural basis of human error processing: Reinforcement learning, dopamine, and the error-related negativity. Psychol Rev, 109: 679709, 2002.

39) Themanson JR, Pontifex MB, Hillman CH. Fitness and action monitoring: Evidence for improved cognitive flexibility in young adults. Neuroscience, 157: 319-328, 2008.

40) Picton TW, Stuss DT, Champagne SC, Nelson RF. The effects of age on human event-related potentials. Psychophysiology, 21: 312-325, 1984.

41) Hatta A, Nishihira Y, Kim SR, Kaneda T, Kida T, Kamijo K, Sasahara M, Haga S. Effects of habitual moderate exercise on response processing and cognitive processing in older adults. Jpn J Physiol, 55: 29-36, 2005.

42) Heil M, Osman A, Wiegelmann J, Rolke B, Hennighausen E. N200 in the Eriksen-task: inhibitory executive processes. J Psychophysiol, 14: 218-225, 2000.

43) Hillman CH, Motl RW, Pontifex MB, Posthuma D, Stubbe JH, Boomsma DI, de Geus EjC. Physical activity and cognitive function in a cross-section of younger and older community-dwelling individuals. Health 
Psychol, 25: 678-687, 2006.

44) Doucet C, Stelmack RM. The effect of response execution on P3 latency, reaction time, and movement time. Psychophysiology, 36: 351-363, 1999.

45) Spirduso WW. Reaction and movement time as a function of age and physical activity level. J Gerontol, 30: 435-440, 1975.
46) American College of Sports Medicine. ACSM's Guidelines for exercise testing and Prescription, 8th Edition, Williams Wilkins, Philadelphia, 2009.

47）厚生労働省運動所要量・運動指針の策定検討会. 健康 づくりのための運動指針2006 生活習慣病予防のため に〜エクササイズガイド2006. (2006). 